\title{
The Impact of Resistance Exercise on Skeletal Muscle in Older Adults: A Literature Review
}

\author{
Ahmad G. Butt, BSc Student [1]* \\ [1] Department of Biology, University of Western Ontario, London, Ontario, Canada N6A3K7 \\ *Corresponding Author: abutt58@uwo.ca
}

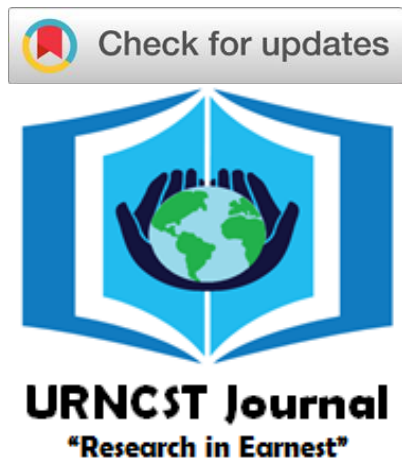

\begin{abstract}
Introduction: Sarcopenia is a prevalent disease characterized by the progressive loss of skeletal muscle mass and strength in older adults. Sarcopenia is associated with decreased mobility, quality of life; impaired metabolism, cell signalling; as well as an increased likelihood of disease, infection, falls, and early mortality rates. Resistance exercise (RE, i.e., weight-lifting) is an efficacious, non-pharmacological intervention used to mitigate the impacts of sarcopenia. The aim of this literature review is to summarize the effects of resistance exercise on skeletal muscle mass, strength, power, and function in communitydwelling older adults, as well as provide general resistance exercise recommendations for older adults to effectively counter sarcopenia.

Methods: We conducted a literature review to assess the impact of resistance exercise on muscle mass, muscle strength, muscle power, and functional capacity in older adults based on three primary criteria: 1) tested healthy, community dwelling participants $\geq 60$ years old; 2 ) assessed the effects of RE on at least one of the aforementioned outcomes; and 3) were peerreviewed and written in English.

Results: Studies involving both sexes and various RE programs regularly show increased skeletal muscle mass and strength following RE training. Additionally, RE appears to improve older adults' neuromuscular performance, though improvements are significantly higher following high-intensity RE sessions. Further, RE improves skeletal muscle function as measured by various qualitative and quantitative tests. Although no specific RE program has been definitively shown to optimally support skeletal muscle adaptation in all older adults, RE, even in small doses, is clearly beneficial for older adults' skeletal muscle health.

Discussion: Undoubtedly, RE has shown to be an efficacious treatment for sarcopenia. To achieve a more comprehensive understanding of how RE counteracts sarcopenia, further research - particularly well controlled randomized trials - are needed to elucidate the cellular processes underlying skeletal muscle's deterioration with advancing age and subsequent response to $\mathrm{RE}$.

Conclusion: Taken all together, RE has a positive impact on skeletal muscle mass, strength, neuromuscular performance, and muscle function in older adults.
\end{abstract}

Keywords: resistance exercise; sarcopenia; muscle mass; muscle strength; neuromuscular performance; muscle power; muscle function; functional capacity

\section{Introduction}

Sarcopenia is a disease characterized by the progressive loss of skeletal muscle mass and strength at rates of $\sim 1 \%$ and $\sim 2-3 \%$ per year, respectively $[1,2]$. Sarcopenia presents in a substantial proportion of older adults, and recent estimates place the prevalence of sarcopenia at $1-29 \%$ in community-dwelling populations, 14-33\% in long-term care adults, and $\sim 10 \%$ in acute healthcare populations [3], though prevalence rates can also vary by ethnicity and country [4]. Importantly, the loss of muscle mass and strength yields cascading molecular and systemwide adverse effects in the human body, such as decreased muscle power [5], mobility [6], and quality of life [7]; impaired metabolism [8] and cell signalling [9]; as well as an increased susceptibility to disease and infection [10], risk of falls [11], and early mortality rates [12]. In addition to physiological impairments, the hospitalization of sarcopenic individuals poses a significant economic burden for patients and healthcare systems - \$40.4 billions in the United States alone [13]. Undoubtedly, feasible and effective treatments are needed to mitigate the impacts of sarcopenia.

Resistance exercise (RE, i.e., weight-lifting) is a simple, safe, and efficacious non-pharmacological intervention $[14,15]$ used to mitigate the impacts of sarcopenia [16]. RE potently stimulates skeletal muscle anabolism [17-19]; hence, progressive bouts of RE, especially when paired with dietary protein ingestion, result 
UNDERGRADUATE RESEARCH IN NATURAL AND CLINICAL SCIENCE AND TECHNOLOGY (URNCST) JOURNAL Read more URNCST Journal articles and submit your own today at: https://www.urncst.com

in accretion of skeletal muscle proteins and increased skeletal muscle volume (i.e., hypertrophy) [20]. Indeed, RE has been shown to be an effective intervention in treating sarcopenia and lead to increased skeletal muscle strength and mass [21-24], and enhanced flexibility [25].

Researchers continue to investigate the efficacy of different RE training weights, intensities, durations, and frequencies [26], but an aperture of RE-specific dialogues exists within sarcopenia-related literature. The American College of Sports Medicine has released recommendations on optimal progressive RE for older adults [27]; however, researchers have confirmed these findings to be scant because they contain author bias and misrepresent the specified population [28]. Researchers have also compared $\mathrm{RE}$ to alternate treatments of sarcopenia, such as testosterone replacement and growth factors, and favoured $\mathrm{RE}$ in treating sarcopenia over alternative treatments. $[16,21]$. Hence, the primary purpose of this literature review is to summarize the effects of resistance exercise on skeletal muscle mass, strength, power, and function in communitydwelling older adults. Additionally, we provide well researched exercise prescriptions and recommendations for older adults to effectively counter sarcopenia.

\section{Methods}

We conducted a literature search targeting research focused on the impact of resistance exercise on muscle mass, muscle strength, muscle power, and functional capacity in older adults. Eligible studies: 1) tested healthy, community dwelling participants $\geq 60$ years old; 2) assessed the effects of RE on at least one of the aforementioned outcomes; and 3) were peer-reviewed and written in English. Publications were collated using PubMed database and important key words included in the search consisted of seniors, older adults, resistance exercise, resistance training, sarcopenia, weight training, muscle mass, muscle strength, muscle function, skeletal muscle, endurance, and muscle power. While most of the studies retrieved solely examined the impact of RE on skeletal muscle, it is worth mentioning that some of the studies also looked at the impact of combining protein intake with RE on skeletal muscle conditions since protein ingestion is linked to muscle gains. The literature search was performed by a single individual and the papers retrieved using the search were subsequently reviewed to ensure alignment with criteria, and thus minimizing bias.

\section{Results}

$\underline{\text { Resistance Exercise Increases Skeletal Muscle Mass and }}$ $\underline{\text { Strength }}$

Numerous researchers have investigated how RE impacts skeletal muscle mass and strength. In all reviewed studies, RE resulted in an improvement in both muscle mass and strength. Many of the studies reviewed involved a specific type of RE called progressive resistance exercise (PRE), which is an exercise intervention in which exercise load increases proportional to individual's strength. For example, researchers conducted a 10-week randomized trial comparing the effect of 1 hour/week of PRE to muscleflexibility exercise sessions in 40 older adults. Significant increases in quadricep strength $(7.7 \%$ for right sided quadricep; $9.9 \%$ for left sided quadricep) and left sided bicep strength $(15.2 \%)$ were observed in the PRE group compared with the flexibility group [29]. However, there was a decrease seen in right sided bicep strength in PRE group $(-2.2 \%)$, attributed to a significantly higher right bicep baseline strength in the flexibility group compared to PRE group [29]. In another study of 25 older adults, researchers showed that 6-weeks of PRE yielded increases in muscle strength and mass regardless of sex; specifically, RE increased muscle strength by $32 \%$ and muscle quality - force generated per unit of muscle tissue, [30] - by $31 \%$ [31].

To study the large-scale effect of RE, meta-analyses have been performed to formulate more robust conclusions. Latham et al. conducted a meta-analysis of 62 trials involving 3674 older adult subjects, and found PRE improved muscle strength $(\mathrm{SMD}=0.68$, 95\% $\mathrm{CI}=[0.52,0.84])[32]$. The analysis, however, did find that the current data cannot determine the effect of PRE on physical disability, which needs further research. Metaanalyses have also studied how RE-gains can be optimized. In an analysis of 680 subjects (aged $33 \pm 18$ years), Cermak et al. investigated if protein supplementation potentiates $\mathrm{RE}$ adaptations [20], since RE and amino acid provision have a synergistic effect on muscle protein synthesis [20]. Cermak et al. found that $\mathrm{RE}$ and protein supplementation collectively lead to significant improvements in skeletal muscle mass and strength [20]. Moving forward, researchers would do well to conduct a similar analysis in older adults.

Resistance exercise has shown similar increases in both skeletal muscle mass and strength regardless of sex [2,23,33-35]. Longitudinal research has shown a 2-fold greater loss of muscle strength in older males compared to females with aging [5]. RE is particularly useful because even with varying intensity, frequency, and modality, a RE regimen can result in significant improvements in muscle strength and mass in both sexes. A systematic review of several databases showed that RE causes increases of 6.6$37 \%$ in skeletal muscle strength and $3.4-7.5 \%$ in muscle mass depending on the mode (frequency, intensity, set, repetitions) of RE. All routines that have frequency of anywhere from 1-6 sessions/week weekly showed a significant increase in muscle strength when at least 1-3 sets of 6-15 repetitions with $30-70 \%$ one repetition maximum (1RM) - the maximum weight an individual can lift with exerted power in a single repetition - were performed [24]. Overall, RE unequivocally results in increased skeletal muscle mass and strength. Studies involving both sexes and different modes of RE collectively show a significant improvement in muscle mass and strength. 
UNDERGRADUATE RESEARCH IN NATURAL AND CLINICAL SCIENCE AND TECHNOLOGY (URNCST) JOURNAL Read more URNCST Journal articles and submit your own today at: https://www.urncst.com

Improvements in Neuromuscular Performance

Neuromuscular performance is measured in terms of muscle power: the product of force and contractile velocity [10]. Sarcopenia is associated with a decline in muscle power, and thus also results in a decline in neuromuscular performance. Quantitative measures used to examine the impact of RE on neuromuscular performance include the chair rise and 6-meter backward tandem walk tests [36]. Using these measures, Taaffe et al. [36] found consistent improvements of neuromuscular performance in a study comparing 1, 2, or $3 \mathrm{RE}$ sessions/week for 24 weeks. All groups resulted in improved neuromuscular performance in the chair rise test - significantly decreased time required to rise from chair 5 times compared to control - with no significant difference observed between frequencies. All groups' neuromuscular performance tested using the 6-meter backward tandem improved similarly, but no statistical difference was observed compared to the control group. Notably, other researchers have shown backward tandem test performance improved significantly following RE [37].

Researchers have explored how changing the intensity of RE programs affects power, and whether a significant difference is seen between different intensities. A metaanalysis on literature in PubMed concluded that improvements in neuromuscular performance only occur at high RE intensities (> $85 \%$ of maximum voluntary strength) in both older adults and younger populations, and that the greatest improvements occur if 3-4 RE sessions are completed each week [26]. In line with these results, De Vos et al. compared RE at 20\%, 50\%, and 80\% 1RM, in an 8 week or 12 week trial and showed that muscle power and endurance improved at all intensities, but significantly greater improvements were observed as RE intensity increased, suggesting a dose-response relationship. [38]. Overall, RE appears to improve older adults' neuromuscular performance, but further improvement is seen when RE is completed at a higher intensity.

\section{Improvements in Physical Function}

Skeletal muscle function is frequently quantified with the short performance physical battery test (SPPB) [39], continuous scale-physical functional performance test (CSPFP) [40], and functional reach test [37]. Vikberg et al. researched the effect of 10-week RE program on physical function, as measured by SPPB scores, in pre-sarcopenic older adults [39]. Compared to the control group, total SPPB scores improved significantly $(0.5 \pm 0.4$ points). Similarly, Cress et al. used the CS-PFP to assess muscle function in a 6-month trial. The healthy, community-dwelling subjects performed RE 3 times/week at an intensity of $75-80 \%$ of $1 \mathrm{RM}$ and were compared to a non-exercising control group. The effect size (ES) between total CS-PFP scores for the exercise group was 0.8 and showed a $14 \%$ increase in muscle functionality compared to control group [40]. Greater differences were seen in CS-PFP scores measured through upper body strength $(\mathrm{ES}=0.94)$ than lower body strength $(\mathrm{ES}=0.74)$, but non-significant changes in CS-PFP scores of upper body flexibility or balance and coordination compared to control group, which showed trend of improvements with implementation of RE. Lastly, Granacher et al. [37] also studied functional capacity using the functional reach test; in their study, healthy participants underwent a 13-week 80\% 1RM RE regimen and showed a significant improvement in performance in the functional reach test. Since the functional reach test is also a method of quantifying flexibility, it corroborates the improvement trends seen in Cress et al.'s study [40].

Several systematic reviews have produced similar conclusions as the aforementioned trials. Lopez et al. [24] analyzed functional capacity - the exercise intensity a person can tolerate, reflective of an individual's fitness level - by compiling primary research on different measures of functionality including gait speed, sit to stand test, SPPB test, and Timed Up and Go (TUG) test, which measures time taken to walk $3 \mathrm{~m}$ after rising from a chair and then returning back to the chair [41]. Functional outcomes as measured by the sit to stand test showed largest improvements of $58.1 \%$ while SPPB scores showed smallest improvements of $4.7 \%-11.4 \%$ [24]. Further, Papa et al. [42] focused on research assessing how RE affects skeletal muscle functional mobility, stability, balance, and gait speed in older adults. From the 11 eligible trials, including one cohort over 90 years old, the researchers concluded RE significantly improved functionality.

Researchers have consistently shown improvements in older adults' muscle function when RE is performed, but some have tried to isolate if specific $R E$ variables differentially impact improvements in muscle function. For example, a study comparing participants that performed RE (1 set at individuals' 10RM for all exercises) once, twice, or thrice a week for 16 weeks in 48 older women showed that RE performed 3 days/week yielded the largest increase in skeletal muscle functional performance; importantly, all exercise frequencies showed improvement in functional performance [43]. While RE program variables remain to be optimized, RE clearly improves older adults' skeletal muscle function. Taken altogether, all literature examining $\mathrm{RE}$ conclude that it appears to be an efficacious method for treating sarcopenia as it results in improvements in skeletal muscle mass, strength, power, and function (Table 1).

\section{Exercise Prescription and Recommendations}

Researchers have consistently shown RE positively impacts skeletal muscle mass, strength, power, and function, but it is difficult to elucidate one RE program that maximizes these phenotypic adaptations. This is due, largely, to the diverse RE programs examined in the literature and individual factors that must be considered when prescribing exercise [22]. While quantitatively determining the optimal $\mathrm{RE}$ prescription is outside the scope of this literature review, some primary and secondary sources were reviewed to develop general RE guidelines for older adults. 
UNDERGRADUATE RESEARCH IN NATURAL AND CLINICAL SCIENCE AND TECHNOLOGY (URNCST) JOURNAL Read more URNCST Journal articles and submit your own today at: https://www.urncst.com

Table 1. Summary of key primary articles included in this review

\begin{tabular}{|c|c|c|c|}
\hline Authors & Study Criteria & Main Findings & $\begin{array}{l}\text { Supporting } \\
\text { Reference }\end{array}$ \\
\hline $\begin{array}{l}\text { Barrett \& } \\
\text { Smerdely }\end{array}$ & $\begin{array}{l}\text { - Randomized control trial (RCT) with } \\
20 \text { participants performing PRE and } 20 \\
\text { performing flexibility exercise. } \\
\text { - Age range }=63.9-69.2 \text { years old. }\end{array}$ & $\begin{array}{l}\text { PRE results in greater improvements in skeletal } \\
\text { muscle strength, gait, and balance in seniors } \\
\text { compared with flexibility exercise. }\end{array}$ & {$[29]$} \\
\hline Scanlon et al. & $\begin{array}{l}\text { - RCT with } 25 \text { participants performing } 6 \\
\text { weeks of PRE. } \\
\text { - All participants > } 60 \text { years old. }\end{array}$ & $\begin{array}{l}\text { Six weeks of PRE results in a significant } \\
\text { increase in muscle strength, muscle quality, and } \\
\text { muscle morphology regardless of sex. There are } \\
\text { no differences seen between sexes. }\end{array}$ & {$[31]$} \\
\hline Charette et al. & $\begin{array}{l}\text { - Twelve weeks RE program with } 27 \\
\text { female participants divided into a } \\
\text { control or exercise group. } \\
\text { - Mean age }=69 \pm 1 \text { years old. }\end{array}$ & $\begin{array}{l}\text { RE results in significant increases in muscle } \\
\text { strength in senior women. These improvements } \\
\text { can be attributed partially to increase in cross } \\
\text { sectional area of type II muscle fiber. }\end{array}$ & [33] \\
\hline $\begin{array}{l}\text { Wieser and } \\
\text { Haber }\end{array}$ & $\begin{array}{l}\text { - Twelve weeks RE program with male } \\
\text { and female subjects ( } 24 \text { in total) and } \\
\text { frequency of } 2 \text { sessions/week. } \\
\text { - Mean age }=76.2 \pm 3.2 \text { in exercise } \\
\text { group and } 76.6 \pm 2.7 \text { in control group. }\end{array}$ & $\begin{array}{l}\text { RE results in significant improvements in } \\
\text { muscle strength as well as increase in the fat } \\
\text { free body mass in both male and female } \\
\text { subjects. }\end{array}$ & {$[34]$} \\
\hline Mayer et al. & $\begin{array}{l}\text { - Meta-analysis conducted using PubMed } \\
\text { database focusing on impact of strength } \\
\text { training on individuals older than } 60 \text {. }\end{array}$ & $\begin{array}{l}\text { PRE in seniors is an efficient exercise } \\
\text { intervention since it can reduce sarcopenia } \\
\text { through improvements in skeletal muscle } \\
\text { compositions and can also be helpful for } \\
\text { retaining motor function. }\end{array}$ & {$[26]$} \\
\hline de Vos et al. & $\begin{array}{l}\text { - RCT with } 112 \text { participants performing } \\
\text { either } 20 \%, 50 \% \text {, or } 80 \% \text { 1RM RE for } \\
8-12 \text { weeks and a frequency of } 2 \\
\text { sessions/week. } \\
\text { - Mean age }=69 \pm 6 \text { years old. }\end{array}$ & $\begin{array}{l}\text { All intensities (low, moderate, high) of 1RM } \\
\text { RE result in noticeable improvements in } \\
\text { skeletal muscle power, strength, and endurance. } \\
\text { However, higher intensities ( } 80 \% \text { ) result in the } \\
\text { highest improvements in all variables } \\
\text { examined. }\end{array}$ & {$[38]$} \\
\hline Lopez et al. & $\begin{array}{l}\text { - Meta-analysis conducted using several } \\
\text { databases examining impact of RE on } \\
\text { muscle mass, strength, power, } \\
\text { functional capacity, and risk of falls in } \\
\text { elderly. }\end{array}$ & $\begin{array}{l}\text { To achieve optimal improvements in muscle } \\
\text { strength, power, and functional capacity, an RE } \\
\text { routine should include 1-6 sessions/week, 1-3 } \\
\text { sets of 6-15 reps, and 30-70\% 1RM RE. }\end{array}$ & {$[24]$} \\
\hline Vikberg et al. & $\begin{array}{l}\text { - Ten weeks RE program with } 36 \\
\text { participants in exercise group and } 34 \\
\text { subjects in control group. } \\
\text { - Mean age }=70.9 \pm 0.03 \text { years old. }\end{array}$ & $\begin{array}{l}\text { SPPB test scores showed an increase in RE } \\
\text { group compared with controls. Additionally, } \\
\text { RE result in improvements in all measured } \\
\text { body composition. Hence, RE is an effective } \\
\text { method to prevent and manage pre-sarcopenia } \\
\text { and sarcopenia. }\end{array}$ & [39] \\
\hline Cress et al. & $\begin{array}{l}\text { - Six months RCT with } 49 \text { participants in } \\
\text { exercise group performing } 3 \mathrm{RE} \\
\text { sessions/week at } 75-80 \% 1 \mathrm{RM} \text { intensity } \\
\text { and } 26 \text { participants in control group. } \\
\text { - Mean age }=76 \pm 4 \text { years old. }\end{array}$ & $\begin{array}{l}\text { Participants in RE group exhibit a significant } \\
\text { increase in muscle strength and CS-PFP scores } \\
\text { but there is no difference in sickness impact or } \\
\text { quality of life compared with control group. }\end{array}$ & {$[40]$} \\
\hline Farinatti et al. & $\begin{array}{l}\text { - } 16 \text { weeks RE program consisting of } 48 \\
\text { women participants divided into exercise } \\
\text { group performing } 10 \mathrm{RM} \text { either } 1,2 \text {, or } 3 \\
\text { times per week, or control group. } \\
\text { - Mean age }=77.7 \pm 8.9 \text { years old }\end{array}$ & $\begin{array}{l}\text { All exercise groups }(1,2 \text {, or } 3 \text {-days } \\
\text { exercise/week) exhibited increases in skeletal } \\
\text { muscle performance and strength. However, } \\
\text { individuals that performed RE } 3 \text { days/week } \\
\text { displayed largest improvements. }\end{array}$ & [43] \\
\hline
\end{tabular}


UNDERGRADUATE RESEARCH IN NATURAL AND CLINICAL SCIENCE AND TECHNOLOGY (URNCST) JOURNAL Read more URNCST Journal articles and submit your own today at: https://www.urncst.com

\section{Exercise Prescription and Recommendations}

Researchers have consistently shown RE positively impacts skeletal muscle mass, strength, power, and function, but it is difficult to elucidate one RE program that maximizes these phenotypic adaptations. This is due, largely, to the diverse RE programs examined in the literature and individual factors that must be considered when prescribing exercise [22]. While quantitatively determining the optimal $\mathrm{RE}$ prescription is outside the scope of this literature review, some primary and secondary sources were reviewed to develop general RE guidelines for older adults.

A study comparing differences in high intensity RE (3 times/week at $80 \% 1 \mathrm{RM}$ ) to variable RE (3 times/week at $80 \%, 65 \%$, and $50 \% 1 \mathrm{RM}$ ) showed similar increases in muscle strength and fat free mass in both groups, but only the variable group improved the carrying objects task, suggesting that variable RE may favourably improve tasks reflecting daily activities [44]. Another study compared the effects of eccentric (muscle-lengthening) and concentric (muscle-shortening) RE on muscle strength and fitness [45]. Several quantitative and qualitative measures of muscle strength, mobility, and posture improved more in the eccentric RE group compared to concentric RE group, suggesting that eccentric RE-induced adaptations are superior compared to concentric-RE.

In 2009, the American College of Sports Medicine published a protocol for optimal RE sessions that included frequency, intensity, and set recommendations based on an individual's exercise experience (novice, intermediate, advanced) and emphasized that total body, rather than localized, RE should be prioritized [27]. However, according to Fisher et al., this protocol was deemed to misrepresent the specified populations, lack appropriate evidence, and include detection bias [28]. Subsequently, their team provided more extensive, evidence-based recommendations. These authors provided individuals with general RE guidelines that they can incorporate into their own regimens, and also examined the role of different RE modes to maximize RE gains for different fitness level. Performing anywhere from 8-12 repetitions demonstrated improvements in muscle endurance and strength, but there is no significant difference in improvements between the variable repetitions. Additionally, they found that 1-2 weekly RE sessions are sufficient to improve most major muscle groups. Furthermore, these researchers concluded that various RE modalities, such as free weight RE, machine based RE, and bodyweight RE, similarly increase skeletal muscle strength. However, there does seem to be a decreased risk of injury associated with machine based RE compared to free weight and body weight RE [28].

Although no specific RE program has been definitively shown to optimally support skeletal muscle adaptation in all older adults, ample research exists on different RE types, frequencies, and intensities. Regardless of the variability in these $\mathrm{RE}$ routines, it is clear that the positive benefits of $\mathrm{RE}$ can be seen with as little as 1 weekly RE session, even at low intensities (20\% 1RM) [38]. Collating the results, recommendations have been made below based on RE routines that result in optimal improvements in skeletal muscle mass and strength, neuromuscular performance, muscle function, as well recommended general guidelines pertaining to optimal $\mathrm{RE}$ regimens.

1. Muscle mass and strength: To achieve noticeable increases in muscle mass and strength, RE routines should consist of 1-6 sessions/week with at least 13 sets of 6-15 repetitions and 30-70\% 1RM [24].

2. Neuromuscular Performance: Higher intensities (>85\% of maximum voluntary strength) RE along with 3-4 RE sessions results in optimal improvements in neuromuscular performance [26].

3. Physical Function: Since physical function is a broad group quantified by a plethora of tests, suggesting an optimal RE routine that would result in largest improvements in all tests is difficult. However, greater RE frequency ( $\geq 3$ days/week) do result in optimal functionality improvements [43].

4. Exercise Prescription: While an optimal RE routine would depend on an individual's lifestyle and body composition, it is recommended that all routines should include at least 8-12 reps with 1-2 RE weekly RE sessions [28].

\section{Discussion}

Within this review we have showcased how RE affects skeletal muscle mass, strength, neuromuscular performance, function, and also compared different RE programs to provide evidence-based RE recommendations. While sex differences exist within rates of sarcopenic declines [5], RE can significantly increase muscle mass and strength, regardless of sex. Comparing different RE modalities, intensities, frequencies, and sets consistently show similar positive improvements in muscle mass and strength. A slightly different trend presents when considering neuromuscular performance. While different RE intensities all show improvements in neuromuscular performance, researchers have found optimal improvements at higher RE intensities [26,38]. Similarly, all measures of muscle functionality have shown improvements with implementation of RE. Additionally, in this literature review, we have discussed exercise prescriptions and optimal RE regimens. While the optimal RE routine varies from person to person, Fisher et al. [28] have provided us with well-constructed guidelines and other studies have provided us with details on how various types of RE can impact muscle adaptations. Eccentric RE has shown to be more effective than concentric RE in improving muscle strength, mobility, and posture [45]; variable RE routines have shown to be more effective than high intensity RE routines in daily activity tasks [44]. When considering RE as a treatment for sarcopenia, protein nutrition cannot be 
UNDERGRADUATE RESEARCH IN NATURAL AND CLINICAL SCIENCE AND TECHNOLOGY (URNCST) JOURNAL Read more URNCST Journal articles and submit your own today at: https://www.urncst.com

forgotten. While this review focuses solely on RE, nutrient and protein supplementation certainly interact synergistically with $\mathrm{RE}$ to optimize skeletal muscle anabolism $[3,14,46]$.

The cellular mechanisms governing muscle strength and mass increases following RE are not fully understood; however, novel transcriptomic and proteomic techniques are helping these physiological processes be better understood [47]. Through these techniques [47], hypertrophy of type I and type II muscle fibers has shown to accompany increases in muscle mass and strength due to $\mathrm{RE}$ and contribute to the gains seen [20,33,48,49]. Morton et al. [49] studied how RE load affects skeletal muscle fibre hypertrophy in younger participants $(22 \pm 3$ years old) and found that higher RE intensity $(>60 \%$ of voluntary maximum strength) were crucial to stimulate hypertrophy of type II muscle fibres. Importantly, the authors concluded that when RE is performed to the point of task failure (i.e., volitional fatigue), skeletal muscle fibers hypertrophy regardless of RE load. These researchers provide us with a more comprehensive understanding of the prerequisites for skeletal muscle hypertrophy, and researchers would do well to examine this phenomenon in older adults. Importantly, this understanding will allow to better analyze how muscle hypertrophy is a phenomenon involved in improving sarcopenic conditions in response to RE, and the factors affecting RE induced hypertrophy such as load difference.

A plethora of researchers have investigated REinduced phenotypic and functional changes in skeletal muscle. For instance, Johnston et al. have hypothesized an existing link between the mitochondrial theory of aging and sarcopenia that may be improved with RE [50]. According to the mitochondrial theory of aging, aging results in a cycle of cellular declines that are initiated with a buildup of mutagenic reactive oxygen species (ROS). The accumulation of these ROS results in somatic mutations of mitochondrial encoding DNA (mtDNA). Consequently, mutated mtDNA leads to disrupted protein translation of essential mitochondrial proteins including electron transport chain (ETC) enzymes, resulting in increased ROS. All of these cellular changes promote sarcopenia. RE has demonstrated to directly decrease ROS production [50], which are starting products that initiate this deleterious cycle. This data suggests that RE directly improves health by modifications involved at the cellular levels. However, it is important to recognize the mitochondrial theory of aging as only one of numerous cellular changes associated with aging. Therefore, while the mitochondrial theory of aging does provide an insight on a specific cellular change seen with RE, the complexity of cellular changes associated with aging is much more extensive and many areas warrant further research.

Original research focused on $\mathrm{RE}$ often conceals adverse events so researchers must be fully transparent to maintain older adults' safety when completing RE programs. This is imperative since, currently, there is uncertainty surrounding adverse effects of RE. Hence, clinicians need to be cautious implementing $\mathrm{RE}$ as a universal sarcopenic intervention because there is a risk of injury, especially at higher intensities [32]. This can be attributed to sarcopenic patients retaining an increased risk of falls which endangers them to fractures and injuries [11]. Further, due to the impairments experienced in sarcopenia, affected individuals are also at a great risk of hospitalization, early mortality, and dependence [5]. Thus, clinicians need to ensure a sarcopenic patient is fit enough to undergo a specific RE regimen before implementing it, otherwise the perils can outweigh the benefits.

It is important to note some limitations did arise during the writing of this literature review. Importantly, during the initial literature search period, there was only one individual involved in searching for and sorting the studies. This introduces the possibility of bias. To minimize this, the literature search was subsequently reviewed by a second individual to ensure all papers met selection criteria initially agreed upon. Additionally, due to time constraint, a comprehensive systematic review could not have been performed which meant that providing extensive quantified exercise prescriptions was not possible due to the complexity and individuality of constructing RE routines. Instead, we provided evidence-based general guidelines that fit $\mathrm{RE}$ routine for most individuals regardless of variability.

\section{Conclusions}

Taken all together, RE certainly has a positive impact on skeletal muscle mass, strength, neuromuscular performance, and muscle function in older adults. The current body of evidence suggests that RE is an appropriate intervention to mitigate and delay the effects of sarcopenia. While research remains to refine an optimal RE program, older adults would undoubtedly benefit from making RE a routine part of their everyday life.

\section{List of Abbreviations Used}

RE: resistance exercise

PRE: progressive resistance exercise

1RM: one repetition maximum

SPPB: short performance physical battery

CS-PFP: continuous scale-physical functional performance ES: effect size

TUG: Timed Up and Go

RCT: randomized controlled trial

ROS: reactive oxygen species

mtDNA: mitochondrial DNA

ETC: electron transport chain

Conflicts of Interest

$\mathrm{AB}$ declares no conflicts of interest. 
UNDERGRADUATE RESEARCH IN NATURAL AND CLINICAL SCIENCE AND TECHNOLOGY (URNCST) JOURNAL Read more URNCST Journal articles and submit your own today at: https://www.urncst.com

\section{Ethics Approval and/or Participant Consent}

This study did not require ethics approval and/or participant consent as it is a literature review.

\section{Authors' Contributions}

$\mathrm{AB}$ : made substantial contributions to the conception and design of the work, conducted literature review, analysis and interpretation, and drafted the manuscript, and gave final approval of the version to be published.

\section{Acknowledgements}

$\mathrm{AB}$ would like to thank the URNCST Journal for the opportunity to submit this manuscript as part of the Mentored Paper initiative. AB would also like to thank Brad S. Currier for his support, guidance, and constructive feedback throughout the composition of this manuscript.

\section{Funding}

This study was not funded.

\section{References}

[1] del Campo Cervantes JM, Macías Cervantes MH, Monroy Torres R. Effect of a Resistance Training Program on Sarcopenia and Functionality of the Older Adults Living in a Nursing Home. J Nutr Health Aging. 2019 Nov 1;23(9):829-36. https://doi.org/ 10.1007/s12603-019-1261-3

[2] Goodpaster BH, Park SW, Harris TB, Kritchevsky SB, Nevitt M, Schwartz AV, et al. The Loss of Skeletal Muscle Strength, Mass, and Quality in Older Adults: The Health, Aging and Body Composition Study. J Gerontol Ser A. 2006 Oct 1;61(10):1059-64. https://doi.org/10.1093/gerona/61.10.1059

[3] Cruz-Jentoft AJ, Landi F, Schneider SM, Zúñiga C, Arai H, Boirie Y, et al. Prevalence of and interventions for sarcopenia in ageing adults: a systematic review. Report of the International Sarcopenia Initiative (EWGSOP and IWGS). Age Ageing. 2014 Nov 1;43(6):748-59. https://doi.org/10.1093/ageing/afu115

[4] Shafiee G, Keshtkar A, Soltani A, Ahadi Z, Larijani B, Heshmat R. Prevalence of sarcopenia in the world: a systematic review and meta- analysis of general population studies. J Diabetes Metab Disord. 2017;16:21. https://doi.org/10.1186/s40200-017-0302-X

[5] Hunter GR, McCarthy JP, Bamman MM. Effects of Resistance Training on Older Adults. Sports Med. 2004 Apr 1;34(5):329-48. https://doi.org/10.2165/ 00007256-200434050-00005

[6] Morley JE, Abbatecola AM, Argiles JM, Baracos V, Bauer J, Bhasin S, et al. Sarcopenia With Limited Mobility: An International Consensus. J Am Med Dir Assoc. 2011 Jul 1;12(6):403-9. https://doi.org/10.1016/ j.jamda.2011.04.014

[7] Beaudart C, Reginster JY, Petermans J, Gillain S, Quabron A, Locquet M, et al. Quality of life and physical components linked to sarcopenia: The SarcoPhAge study. Exp Gerontol. 2015 Sep;69:10310. https://doi.org/10.1016/j.exger.2015.05.003

[8] Wolfe RR. The underappreciated role of muscle in health and disease. Am J Clin Nutr. 2006 Dec 1;84(3):475-82. https://doi.org/10.1093/ajcn/84.3.475

[9] Nielsen S, Pedersen BK. Skeletal muscle as an immunogenic organ. Curr Opin Pharmacol. 2008 Jun;8(3):346-51.

https://doi.org/10.1016/j.coph.2008.02.005

[10] Lavin KM, Roberts BM, Fry CS, Moro T, Rasmussen $\mathrm{BB}$, Bamman MM. The Importance of Resistance Exercise Training to Combat Neuromuscular Aging. Physiology. 2019 Feb 6;34(2):112-22. https://doi.org/ 10.1152/physiol.00044.2018

[11] Schaap LA, van Schoor NM, Lips P, Visser M. Associations of Sarcopenia Definitions, and Their Components, With the Incidence of Recurrent Falling and Fractures: The Longitudinal Aging Study Amsterdam. J Gerontol A Biol Sci Med Sci. 2018 10;73(9):1199-204. $\quad$ https://doi.org/10.1093/gerona/ glx245

[12] Srikanthan P, Karlamangla AS. Muscle Mass Index as a Predictor of Longevity in Older-Adults. Am J Med. 2014 Jun;127(6):547-53. $\quad$ https://doi.org/10.1016 /j.amjmed.2014.02.007

[13] Goates S, Du K, Arensberg MB, Gaillard T, Guralnik $\mathrm{J}$, Pereira SL. Economic Impact of Hospitalizations in US Adults with Sarcopenia. J Frailty Aging. 2019;8(2):93-9. https://doi.org/10.14283/jfa.2019.10

[14] Kirk B, Mooney K, Amirabdollahian F, Khaiyat O. Exercise and Dietary-Protein as a Countermeasure to Skeletal Muscle Weakness: Liverpool Hope University - Sarcopenia Aging Trial (LHU-SAT). Front Physiol. 2019;10:445. https://doi.org/10.3389/fphys.2019.00445

[15] Winett RA, Carpinelli RN. Potential health-related benefits of resistance training. Prev Med. 2001 Nov;33(5):503-13. https://doi.org/10.1006/pmed.2001 .0909

[16] Endo Y, Nourmahnad A, Sinha I. Optimizing Skeletal Muscle Anabolic Response to Resistance Training in Aging. Front Physiol. 2020 Jul 23;11. https://doi.org/10.3389/fphys.2020.00874

[17] Atherton PJ, Etheridge T, Watt PW, Wilkinson D, Selby A, Rankin D, et al. Muscle full effect after oral protein: time-dependent concordance and discordance between human muscle protein synthesis and mTORC1 signaling. Am J Clin Nutr. 2010 Nov;92(5):1080-8. https://doi.org/10.3945/ajcn.2010.29819

[18] Morton RW, McGlory C, Phillips SM. Nutritional interventions to augment resistance training-induced skeletal muscle hypertrophy. Front Physiol. 2015;6. https://doi.org/10.3389/fphys.2015.00245

[19] Rennie MJ, Edwards RH, Halliday D, Matthews DE, Wolman SL, Millward DJ. Muscle protein synthesis measured by stable isotope techniques in man: the 
UNDERGRADUATE RESEARCH IN NATURAL AND CLINICAL SCIENCE AND TECHNOLOGY (URNCST) JOURNAL Read more URNCST Journal articles and submit your own today at: https://www.urncst.com

effects of feeding and fasting. Clin Sci Lond Engl 1979. 1982 Dec;63(6):519-23. https://doi.org/ $10.1042 / \mathrm{cs} 0630519$

[20] Cermak NM, Res PT, de Groot LC, Saris WH, van Loon LJ. Protein supplementation augments the adaptive response of skeletal muscle to resistance-type exercise training: a meta-analysis. Am J Clin Nutr. 2012 Dec 1;96(6):1454-64. https://doi.org/10.3945/ ajcn. 112.037556

[21] Borst SE. Interventions for sarcopenia and muscle weakness in older people. Age Ageing. 2004 Nov 1;33(6):548-55. https://doi.org/10.1093/ageing/afh201

[22] Clark BC, Clark LA, Law TD. Resistance Exercise to Prevent and Manage Sarcopenia and Dynapenia. Annu Rev Gerontol Geriatr. 2016 Jan 1;36(1):205-28. https://doi.org/10.1891/0198-8794.36.205

[23] Hunter GR, Treuth MS, Weinsier RL, Kekes-Szabo T, Kell SH, Roth DL, et al. The Effects of Strength Conditioning on Older Women's Ability to Perform Daily Tasks. J Am Geriatr Soc. 1995;43(7):756-60. https://doi.org/10.1111/j.1532-5415.1995.tb07045.x

[24] Lopez P, Pinto RS, Radaelli R, Rech A, Grazioli R, Izquierdo $\mathrm{M}$, et al. Benefits of resistance training in physically frail elderly: a systematic review. Aging Clin Exp Res. 2018 Aug;30(8):889-99. https://doi.org/10.1007/s40520-017-0863-z

[25] Taaffe DR. Sarcopenia: exercise as a treatment strategy. Aust Fam Physician. 2006 Mar;35(3):130. Available from: https://www.racgp.org.au/afp/200603/ $\underline{3608}$

[26] Mayer F, Scharhag-Rosenberger F, Carlsohn A, Cassel M, Müller S, Scharhag J. The Intensity and Effects of Strength Training in the Elderly. Dtsch Ärztebl Int. 2011 May;108(21):359-64. https://doi.org/10.3238/ arztebl.2011.0359

[27] Progression Models in Resistance Training for Healthy Adults: Med Sci Sports Exerc. 2009 Mar;41(3):687708. https://doi.org/10.1249/MSS.0b013e3181915670

[28] Fisher J, Steele J, Bruce-Low S, Smith D. EvidenceBased Resistance Training Recommendations. Med Sport. 2011;15(3):147-62. https://doi.org/10.2478/ v10036-011-0025-x

[29] Barrett C, Smerdely P. A comparison of communitybased resistance exercise and flexibility exercise for seniors. Aust J Physiother. 2002 Jan 1;48(3):215-9. https://doi.org/10.1016/S0004-9514(14)60226-9

[30] Chiles Shaffer N, Fabbri E, Ferrucci L, Shardell M, Simonsick EM, Studenski S. Muscle Quality, Strength, and Lower extremity physical performance in the baltimore longitudinal study of aging. J Frailty Aging. 2017;6(4):183-7. https://doi.org/10.14283/jfa.2017.24

[31] Scanlon TC, Fragala MS, Stout JR, Emerson NS, Beyer KS, Oliveira LP, et al. Muscle architecture and strength: Adaptations to short-term resistance training in older adults. Muscle Nerve. 2014;49(4):584-92. https://doi.org/10.1002/mus.23969

Butt | URNCST Journal (2021): Volume 5, Issue 1

DOI Link: https://doi.org/10.26685/urncst.204
[32] Latham NK, Bennett DA, Stretton CM, Anderson CS. Systematic Review of Progressive Resistance Strength Training in Older Adults. J Gerontol Ser A. 2004 Jan 1;59(1):M48-61. https://doi.org/10.1093/gerona/59.1 M48

[33] Charette SL, McEvoy L, Pyka G, Snow-Harter C, Guido D, Wiswell RA, et al. Muscle hypertrophy response to resistance training in older women. J Appl Physiol. 1991 May 1;70(5):1912-6. https://doi.org/ 10.1152/jappl.1991.70.5.1912

[34] Wieser M, Haber P. The Effects of Systematic Resistance Training in the Elderly. Int J Sports Med. 2007 Jan;28(1):59-65. https://doi.org/10.1055/s-2006924057

[35] Ahtiainen JP, Walker S, Peltonen H, Holviala J, Sillanpää E, Karavirta L, et al. Heterogeneity in resistance training-induced muscle strength and mass responses in men and women of different ages. Age Dordr Neth. 2016 Feb;38(1):10. https://doi.org/ 10.1007/s11357-015-9870-1

[36] Taaffe DR, Duret C, Wheeler S, Marcus R. OnceWeekly Resistance Exercise Improves Muscle Strength and Neuromuscular Performance in Older Adults. J Am Geriatr Soc. 1999;47(10):1208-14. https://doi.org/ 10.1111/j.1532-5415.1999.tb05201.x

[37] Granacher U, Gruber M, Gollhofer A. Resistance training and neuromuscular performance in seniors. Int J Sports Med. 2009 Sep;30(9):652-7. https://doi.org/ 10.1055/s-0029-1224178

[38] de Vos NJ, Singh NA, Ross DA, Stavrinos TM, Orr R, Fiatarone Singh MA. Optimal Load for Increasing Muscle Power During Explosive Resistance Training in Older Adults. J Gerontol Ser A. 2005 May 1;60(5):63847. https://doi.org/10.1093/gerona/60.5.638

[39] Vikberg S, Sörlén N, Brandén L, Johansson J, Nordström A, Hult A, et al. Effects of Resistance Training on Functional Strength and Muscle Mass in 70-Year-Old Individuals With Pre-sarcopenia: A Randomized Controlled Trial. J Am Med Dir Assoc. 2019 Jan;20(1):28-34. https://doi.org/10.1016/ j.jamda.2018.09.011

[40] Cress ME, Buchner DM, Questad KA, Esselman PC, deLateur BJ, Schwartz RS. Exercise: Effects on Physical Functional Performance in Independent Older Adults. J Gerontol A Biol Sci Med Sci. 1999 May 1;54(5):M242-8. https://doi.org/10.1093/gerona/54.5 M242

[41] Podsiadlo D, Richardson S. The Timed "Up \& Go": A Test of Basic Functional Mobility for Frail Elderly Persons. J Am Geriatr Soc. 1991;39(2):142-8. https://doi.org/10.1111/j.1532-5415.1991.tb01616.x

[42] Papa EV, Dong X, Hassan M. Resistance training for activity limitations in older adults with skeletal muscle function deficits: a systematic review. Clin Interv Aging. 2017 Jun 13;12:955-61. https://doi.org/ $\underline{10.2147 / C I A . S 104674}$ 
UNDERGRADUATE RESEARCH IN NATURAL AND CLINICAL SCIENCE AND TECHNOLOGY (URNCST) JOURNAL

Read more URNCST Journal articles and submit your own today at: https://www.urncst.com

[43] Farinatti PTV, Geraldes AAR, Bottaro MF, Lima MVIC, Albuquerque RB, Fleck SJ. Effects of Different Resistance Training Frequencies on the Muscle Strength and Functional Performance of Active Women Older Than 60 Years. J Strength Cond Res. 2013 Aug;27(8):2225-2234. https://doi.org/10.1519/ JSC.0b013e318278f0db

[44] Hunter GR, Wetzstein CJ, McLafferty CL, Zuckerman PA, Landers KA, Bamman MM. High-resistance versus variable-resistance training in older adults. Med Sci Sports Exerc. 2001 Oct;33(10):1759-64. https://doi.org/10.1097/00005768-200110000-00022

[45] Katsura Y, Takeda N, Hara T, Takahashi S, Nosaka K. Comparison between eccentric and concentric resistance exercise training without equipment for changes in muscle strength and functional fitness of older adults. Eur J Appl Physiol. 2019 Jul;119(7):1581-90. https://doi.org/10.1007/s00421019-04147-0

[46] Rom O, Kaisari S, Aizenbud D, Reznick AZ. Lifestyle and Sarcopenia-Etiology, Prevention, and Treatment.
Rambam Maimonides Med J. 2012 Oct 31;3(4). https://doi.org/10.5041/RMMJ.10091

[47] Stokes T, Timmons JA, Crossland H, Tripp TR, Murphy K, McGlory C, et al. Molecular Transducers of Human Skeletal Muscle Remodeling under Different Loading States. Cell Rep. 2020 Aug 4;32(5). https://doi.org/10.1016/j.celrep.2020.107980

[48] Pyka G, Lindenberger E, Charette S, Marcus R. Muscle Strength and Fiber Adaptations to a Year-long Resistance Training Program in Elderly Men and Women. J Gerontol. 1994 Jan 1;49(1):M22-7. https://doi.org/10.1093/geronj/49.1.M22

[49] Morton RW, Sonne MW, Farias Zuniga A, Mohammad IYZ, Jones A, McGlory C, et al. Muscle fibre activation is unaffected by load and repetition duration when resistance exercise is performed to task failure. $\mathbf{J}$ Physiol. 2019;597(17):4601-13. https://doi.org/10 $.1113 / \mathrm{JP} 278056$

[50] Johnston APW, De Lisio M, Parise G. Resistance training, sarcopenia, and the mitochondrial theory of aging. APNM Video Ser. 2007 Dec 21;01(02):191-9. https://doi.org/10.1139/H07-141

\section{Article Information}

Managing Editor: Jeremy Y. Ng

Peer Reviewers: Brad S. Currier, Pallavi Dutta

Article Dates: Received Nov 02 20; Accepted Dec 12 20; Published Jan 2221

\section{Citation}

Please cite this article as follows:

Butt AG. The impact of resistance exercise on skeletal muscle in older adults: A literature review. URNCST Journal. 2021

Jan 22: 5(1). https://urncst.com/index.php/urncst/article/view/204

DOI Link: https://doi.org/10.26685/urncst.204

\section{Copyright}

(C) Ahmad G. Butt. (2021). Published first in the Undergraduate Research in Natural and Clinical Science and Technology (URNCST) Journal. This is an open access article distributed under the terms of the Creative Commons Attribution License (https://creativecommons.org/licenses/by/4.0/), which permits unrestricted use, distribution, and reproduction in any medium, provided the original work, first published in the Undergraduate Research in Natural and Clinical Science and Technology (URNCST) Journal, is properly cited. The complete bibliographic information, a link to the original publication on http://www.urncst.com, as well as this copyright and license information must be included.
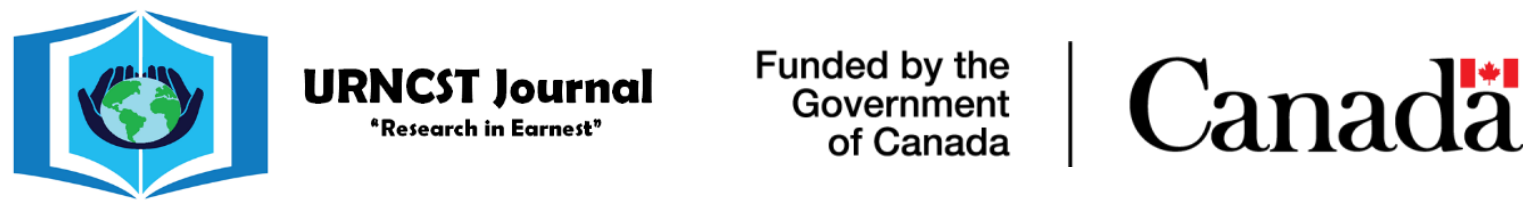

Do you research in earnest? Submit your next undergraduate research article to the URNCST Journal!

| Open Access | Peer-Reviewed | Rapid Turnaround Time | International |

| Broad and Multidisciplinary | Indexed | Innovative | Social Media Promoted |

Pre-submission inquiries? Send us an email at info@ urncst.com | Facebook, Twitter and LinkedIn: @ URNCST

Submit YOUR manuscript today at https://www.urncst.com! 